\title{
Purification and Characterization of Anabaena flos-aquae Phenylalanine Ammonia-Lyase as a Novel Approach for Myristicin Biotransformation
}

\author{
Asmaa M. Arafa ${ }^{1}$, Afaf E. Abdel-Ghany ${ }^{1}$, Samih I. El-Dahmy ${ }^{1}$, Sahar Abdelaziz ${ }^{1}$, Yassin El-Ayouty ${ }^{2}$, \\ and Ashraf S. A. El-Sayed ${ }^{2 *}$ \\ 'Department of Pharmacognosy, Faculty of Pharmacy, Zagazig University, Zagazig 44519, Egypt \\ ${ }^{2}$ Enzymology and Fungal Biotechnology Lab (EFBL), Botany and Microbiology Department, Faculty of Science, \\ Zagazig University, Zagazig 44519, Egypt
}

\begin{abstract}
Phenylalanine ammonia-lyase (PAL) catalyzes the reversible deamination of phenylalanine to cinnamic acid and ammonia. Algae have been considered as biofactories for PAL production, however, biochemical characterization of PAL and its potency for myristicin biotransformation into MMDA (3-methoxy-4, 5-methylenedioxyamphetamine) has not been studied yet. Thus, PAL from Anabaena flos-aquae and Spirulina platensis has been purified, comparatively characterized and its affinity to transform myristicin was assessed. The specific activity of purified PAL from S. platensis $(73.9 \mu \mathrm{mol} / \mathrm{mg} / \mathrm{min})$ and $A$. flos-aquae $(30.5 \mu \mathrm{mol} / \mathrm{mg} / \mathrm{min})$ was increased by about 2.9 and 2.4 folds by gel-filtration comparing to their corresponding crude enzymes. Under denaturing-PAGE, a single proteineous band with a molecular mass of $64 \mathrm{kDa}$ appeared for A. flos-aquae and S. platensis PAL. The biochemical properties of the purified PAL from both algal isolates were determined comparatively. The optimum temperature of $S$. platensis and $A$. flos-aquae PAL for forward or reverse activity was reported at $30^{\circ} \mathrm{C}$, while the optimum $\mathrm{pH}$ for PAL enzyme isolated from $A$. flos-aquae was 8.9 for forward and reverse activities, and S. platensis PAL had maximum activities at $\mathrm{pH} 8.9$ and 8 for forward and reverse reactions, respectively. Luckily, the purified PALs have the affinity to hydroaminate the myristicin to MMDA successfully in one step. Furthermore, a successful method for synthesis of MMDA from myristicin in two steps was also established. Gas chromatography-mass spectrometry (GC-MS) analysis was conducted to track the product formation.
\end{abstract}

Keywords: Phenylalanine ammonia-lyase, purification, properties, myristicin, MMDA

Received: August 6, 2019 Accepted: September 27, 2019

First published online: September 30, 2019

*Corresponding author Phone: +2-01024686495 E-mail:ash.elsayed@gmail.com

Supplementary data for this paper are available on-line only at http://jmb.or.kr.

pISSN 1017-7825 eISSN 1738-8872

Copyright(C) 2020 by The Korean Society for Microbiology and Biotechnology

\section{Introduction}

Phenylalanine ammonia-lyase (PAL, E.C. 4.3.1.5) belongs to the ammonia lyases family [1], and catalyzes the deamination (forward) and hydroamination (reverse) reactions of phenylalanine as substrate $[2,3]$. The forward reaction involves deamination of $L$-phenylalanine ( $L$-Phe) to trans-cinnamic acid $(t$-Ca) and ammonia, while, the reversal reaction involves biotransformation of trans-cinnamic acid to $L$-phenylalanine [4,5], as illustrated in Fig. 1A. PAL is widely distributed in plants, acting as a key enzyme in phenylpropanoid pathway $[6,7]$, controlling the production of secondary metabolites such as flavonoids, coumarins, lignins, stilbenes and phytoalexins [7]. PAL has also been reported found in fungi, yeasts and bacteria [4]. Fungal PAL can utilize $L$-phenylalanine as a carbon and nitrogen source $[5,8]$. Bacterial PAL was reported to be implemented in biosynthesis of secondary metabolites as cinnamamide in Streptomyces verticillatus [9], 3,5-dihydroxy-4-isopropylstilbene in Photorhabdus luminescens and enterocin in Streptomyces maritimus [1,10]. Few studies were documented to the PAL from algae, except Anabaena variabilis, Nostoc punctiforme [11], Dunaliella marina [4] and Anacystis nidulans [12]. Animal $[4]$ and human $[13,14]$ tissues are free of PAL. Recently, there is a growing interest in exploring the biochemical properties of PAL because of its clinical and commercial applications [15]. Chemically modified PAL has been used as a therapy for phenylketonuria (PKU) $[9,16]$, which is an inborn disorder of phenylalanine metabolism caused by deficiency of phenylalanine hydroxylase (PAH), causing cognitive development loss and mental retardation as a result of hyperphenylalaninemia $[17,18]$. Also, PAL has been used for anticancer activity due to its selectivity for phenylalanine by inhibiting the growth of neoplasms in vitro and in lymphoblastic leukemia $[4,15$, 19]. Moreover, reverse pathway of PAL meets the great requirements for $L$-phenylalanine in the food and pharmaceutical industries [15]. As an essential amino acid, $L$-phenylalanine [20] serves as a supplement for 

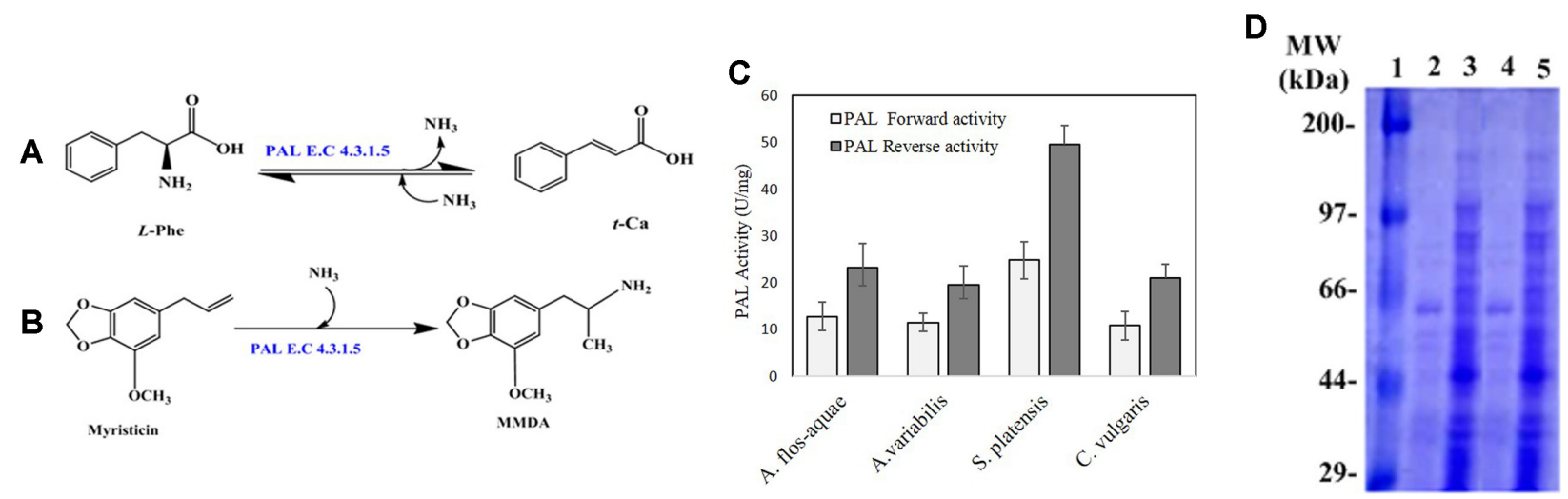

Fig.1. Forward and reverse pathways catalyzed by PAL (A), Proposed biotransformation of myristicin to MMDA by PAL (B), Forward and reverse activities of PAL from different algal isolates (C), SDS-PAGE of the purified PAL from S. platensis and A. flos-aquae (D). Lane 1, broad range marker (Cat\# sc-2361, 6-200 kDa, Santa Cruz Biotechnology, Inc. USA), lane 2 and lane 4 are purified PAL from S. platensis and A. flos-aquae, respectively, lane 3 and lane 5 are crude extracts of S. platensis and A. flos-aquae, respectively.

human nutrition and as a precursor for the synthesis of artificial sweetener aspartame [21-23].

Myristicin (1-allyl-5-methoxy-3,4-methylenedioxybenzene), is a naturally occurring phenylpropanoid derivative $[24,25]$ found in nutmeg [26], cinnamon, parsley, basil, carrot [27], dill [28] and various plants belonging to the Umbelliferae [29]. Myristicin has various applications in the food and cosmetic industries, in treatment of anxiety, stomach cramps, diarrhea, and cholera in addition to having antibacterial, anti-inflammatory, hepatoprotective, anti-cholinergic [27, 30] and insecticidal [31,32] activities. Metabolic conversion of myristicin into 3-methoxy-4, 5-methylenedioxy-amphetamine (MMDA) had been studied in rats [33] and humans [34,35]. MMDA is a potent psychoactive drug [36-38] that has about twice higher activities than those of mescaline [33], with similar activity to 3,4,5-trimethoxyamphetamine (TMA) [39]. MMDA attenuates anxiety and loneliness feelings, suppresses appetite [40] and elevates the mood [35, 41]. MMDA is used for treatment of autism, major depressive disorder, anxiety [42,43], alcohol dependence, Alzheimer's, attention-deficit hyperactivity disorder (ADHD), and parkinsonism-dystonia infantile and schizophrenia [43-45]. MMDA has been used as a psychotherapy adjunct [46], as a useful drug for neurosis treatment [35]. Moreover, another study reported at the American Psychological Association's annual meeting in 2018 that MMDA is used for treatment of social anxiety, depression, and posttraumatic stress disorder [47]. However, production of MMDA is the main technical challenge for its various pharmaceutical applications. MMDA has been synthesized commercially from myristicin by Shulgin [48] and Clark et al., [49], however, the price of MMDA is about 17.8 folds higher than myristicin [50]. Thus, searching for alternative novel methods for production of MMDA with higher yield and low price is an objective for many researchers. Production of MMDA via biotransformation of myristicin with PAL seems to be a novel hypothetical approach for higher yield of MMDA, as proposed in Fig. 1B. From literature, PAL of algal sources was reported to have a higher turnover number, catalytic activity and broad substrate specificity, than plant and fungal and bacterial sources of PAL (https://www.brenda-enzymes.org/enzyme.php?ecno=4.3.1.5). Thus, the objective of this work was to purify PAL from different algal sources, in addition to exploring the potentiality of purified PAL to transform myristicin as substrate into MMDA, using one-step enzymatic synthesis. To the best of our knowledge, nothing has been reported on the production of PAL by green algae like Chlorella vulgaris and bluegreen algae such as Anabaena flos-aquae and Spirulina platensis except Anabaena variabilis var. kashiensis (Bharadwaja) $[5,10]$. In view of this, the second aim of this research is to discover new microbial sources of PAL production. Thus, our report investigates the extraction, purification, and characterization of PAL from A. flosaquae and S. platensis. Moreover, investigation of myristicin biotransformation by purified PAL is the latest aim.

\section{Materials and Methods}

Algal Strains and Culture Conditions

Fifty microbial isolates (twenty fungal isolates, twenty bacterial isolates, and ten algal isolates) were collected from the microbiology laboratory of the Faculty of Science, Zagazig, Zagazig University, Egypt. The fungal isolates were grown on potato dextrose broth media [51], while the bacterial isolates were grown on nutrient broth media [52]. Anabaena flos-aquae and A. variabilis were grown on blue-green medium (BG-11) [53], Spirulina platensis was grown on Zarrouk medium [54], and Chlorella vulgaris was grown on diatom culture medium (DM) [55]. The fungal cultures were incubated for 10 days at $30^{\circ} \mathrm{C}$, while bacterial cultures were incubated at 5 days at $37^{\circ} \mathrm{C}$. Algal cultures were maintained at $27^{\circ} \mathrm{C} \pm 1^{\circ} \mathrm{C}$, except S. platensis, which was incubated at $31 \pm 0.5^{\circ} \mathrm{C}$ under white fluorescent illumination of 30 to $40 \mu \mathrm{Em}-2 \mathrm{~s}-1$ provided by fluorescent tubes (Philips Trulite, Col 82 ). The cultures were exposed to light: dark photoperiod (12:12) and aerated with air current through an electric pump (20 l/h). The $\mathrm{pH}$ of media was adjusted to 7.1 (BG-11), 9.5 (Zarrouk medium) and 6.9 (DM) by $0.1 \mathrm{~N} \mathrm{HCl}$ and /or $\mathrm{NaOH}$ using a Jenway $3510 \mathrm{pH}$ meter. 
Algal Harvesting and Extraction of Phenylalanine Ammonia Lyase (PAL)

The algal cells were harvested by centrifugation at $10,000 \times g\left(4^{\circ} \mathrm{C}\right)$ for $15 \mathrm{~min}$ at mid-logarithmic phase, washed three times with sterile distilled water and the algal masses were stored at $-20^{\circ} \mathrm{C}$. Twenty grams of frozen algal biomass of each strain were separately pulverized in liquid nitrogen and suspended into $50 \mathrm{ml}$ of $100 \mathrm{mM}$ cold Tris-HCl buffer ( $\mathrm{pH} 8.9)$, with $0.2 \% \mathrm{Na}_{2}$-EDTA and $125 \mu \mathrm{l} \beta$-mercaptoethanol. The extracts were centrifuged at $10,000 \times g$ for $10 \mathrm{~min}$ at $4^{\circ} \mathrm{C}$ and the supernatants were used as crude extracts for enzyme assay, protein estimation and purification.

\section{Phenylalanine Ammonia Lyase (PAL) Assay}

The deaminating and hydroaminating activities of the crude enzyme were determined $[1,56,57]$ with slight modifications. Briefly, for deaminating activity, assay was performed using $50 \mu \mathrm{M} L$-phenylalanine, $250 \mu \mathrm{l}$ of enzyme extract, in $2 \mathrm{ml}$ of $100 \mathrm{mM}$ Tris- $\mathrm{HCl}$ buffer ( $\mathrm{pH} \mathrm{8.9)}$ ), and incubated at $37^{\circ} \mathrm{C}$ for $30 \mathrm{~min}$. The reaction was stopped by addition of $500 \mu \mathrm{l}$ of $1 \mathrm{~N} \mathrm{HCl}$ and the absorbance of cinnamic acid was measured at $270 \mathrm{~nm}$. The concentration of cinnamic acid was calculated with regard to standard curve. For hydroamination assay, the reaction ( $2 \mathrm{ml}$ ) contained $100 \mathrm{mM}$ Tris- $\mathrm{HCl}$ buffer ( $\mathrm{pH} 8.9$ ), $200 \mu \mathrm{l}$ of $1 \mathrm{mM}$ trans-cinnamic acid in $5 \mathrm{M} \mathrm{NH}_{4} \mathrm{OH}$ and $200 \mu \mathrm{l}$ of enzyme preparation and was incubated at $37^{\circ} \mathrm{C}$ for $30 \mathrm{~min}$. Formation of $L$-phenyl-alanine as a byproduct was quantitatively estimated at $257 \mathrm{~nm}$ (Rigol ultra-3660 UV-VIS spectrophotometer). One unit (U) of PAL was expressed by the amount of enzyme that catalyzes the formation of $1 \mu \mathrm{M}$ of trans-cinnamic acid/ $L$ phenylalanine per min under optimal assay conditions. The specific activity $(\mathrm{U} / \mathrm{mg})$ was expressed by the enzyme activity in unit per milligram of protein.

The concentration of proteins was estimated by Folin's reagent according to Lowry et al. [58], using bovine serum albumin as standard.

Purification of PAL by Gel-Filtration and Ion-Exchange Chromatography

The crude enzyme from the selected algal isolates was purified using gel-filtration and ion-exchange chromatographic approaches [59-64]. The crude PAL was precipitated with two-fold chilled acetone, and incubated at $-20^{\circ} \mathrm{C}$ for $30 \mathrm{~min}$. The mixture was centrifuged at $6,000 \times g$ for $15 \mathrm{~min}$ at $4^{\circ} \mathrm{C}$, and the supernatant was decanted. The protein pellets were dissolved in $5 \mathrm{ml}$ of $100 \mathrm{mM}$ cold Tris- $\mathrm{HCl}$ buffer ( $\mathrm{pH} \mathrm{8.9)}$ ) as described above, followed by centrifugation at $10,000 \times g$ for $5 \mathrm{~min}$ at $4^{\circ} \mathrm{C}$. Crude extract $(3.5$ and $8 \mathrm{mg}$ protein/ml) of PAL from $S$. platensis and A. flos-aquae, respectively, was applied to a previously equilibrated Sephadex G- 200 column $(30 \mathrm{~cm}$ $\times 2 \mathrm{~cm}$ ), with $100 \mathrm{mM}$ cold Tris- $\mathrm{HCl}$ buffer $(\mathrm{pH} 8.9)$. The column was equilibrated with $100 \mathrm{mM}$ Tris- $\mathrm{HCl}(\mathrm{pH}$ $8.9)$ at flow rate $0.5 \mathrm{ml} / \mathrm{min}$, and the fractions $(1 \mathrm{ml})$ were eluted. The activity of PAL and protein content were measured for each fraction. The molecular homogeneity of the most active fractions of PAL were checked by SDSPAGE, the most active and molecularly homogenous fractions were pooled, collected and concentrated by dialysis (Dialysis Membrane, Size 20, Cat\# 546-00051, Wako Chemicals, USA) with $100 \mathrm{mM}$ Tris-HCl buffer (pH 8.9) at $4^{\circ} \mathrm{C}$, till reduction of the total volume to $2 \mathrm{ml}$. The pooled fractions of PAL were further purified by ion-exchange chromatography with DEAE-cellulose. The partially purified PAL was loaded to the top of DEAE-cellulose column previously equilibrated with $100 \mathrm{mM}$ Tris- $\mathrm{HCl}$ buffer. The enzyme was eluted on the same buffer with gradient concentrations of $\mathrm{NaCl}(100-500 \mathrm{mM})$. The activity of PAL and protein concentration for each fraction were analyzed as described above. The molecular homogeneity of the active fractions was checked by SDS-PAGE analysis, and the molecularly active homogenous fractions were pooled, gathered and concentrated by dialysis, prior to further biochemical analyses.

\section{Subunit Structure and Molecular Mass of Purified PAL}

The subunit structure and molecular mass of the purified PAL from the algal species were determined by the SDSPAGE and native-PAGE $[65,66]$, according to Laemmli [66] with slight modifications $[51,64]$. The protein samples $(50 \mu \mathrm{l})$ were boiled in dissociation loading buffer for $5 \mathrm{~min}$, and then loaded into the wells of stacking gel. The gel running was conducted at $100 \mathrm{~mA}$ for $40 \mathrm{~min}$ (Bio-Rad, Model 2000/200). After running, the gel was immersed in Coomassie brilliant blue stain with gentle shaking at $50 \mathrm{rpm}$, then, the gel was washed by de-staining. The molecular weight of the appeared protein bands was calculated from the inference of protein ladder (Cat\# sc2361, 6-200 kDa, Santa Cruz Biotechnology Inc., USA).

Biochemical Properties of Purified PAL

The biochemical properties of the purified PAL such as reaction temperature, thermal stability, reaction $\mathrm{pH}, \mathrm{pH}$ stability, substrate specificity and effect of various compounds and metals were studied as described previously [51, 62-64]. Michalis-Menten constant $(\mathrm{Km})$, maximum velocity (Vmax), turnover number $\left(k_{\text {cat }}\right)$ and catalytic efficiency $\left(k_{\text {cat }} / \mathrm{Km}\right)$ are the common kinetic parameters that were determined towards the substrates [60].

\section{Enzymatic Synthesis of MMDA with PAL Using Myristicin as Substrate}

Myristicin was isolated and purified from wild Daucus pumilus (Gouan) and its chemical structure was validated from the spectrometric analyses [67, 68]. The biotransformation of myristicin into 3-Methoxy-4, 5methylenedioxyamphetamine (MMDA) was illustrated in Fig. 1B. The proposed mechanism of the hydroamination reactions of myristicin to MMDA using PAL has been postulated by Lovelock [1]. The enzymatic reaction contained $30 \mathrm{mM}$ myristicin (dissolved in acetone) in Tris-HCl buffer ( $\mathrm{pH} 8.0$ ), and $500 \mu$ lof PAL preparation in 5 $\mathrm{ml}$ total volume, and the reaction was incubated at $37^{\circ} \mathrm{C}$ for $1 \mathrm{~h}$ with shaking at $120 \mathrm{rpm}$. Blanks of enzyme free substrate and substrate free enzyme were used as baseline. The reaction $\mathrm{pH}$ was adjusted to $\mathrm{pH} 12$ with the 
addition of $10 \mathrm{~N} \mathrm{NaOH}$ and the product was extracted with diethyl ether three times $(20 \mathrm{ml}$ each). Upper phase was combined and concentrated. The concentrated residue was dissolved in $500 \mu \mathrm{l}$ of methanol and analyzed using gas chromatography-mass spectrometry (GC-MS).

\section{Chemical Synthesis of MMDA}

Chemical synthesis of MMDA was performed by hydrohalogenation followed by amination reactions according to Clark, et al., [49] with slight modification. Briefly, hydrohalogenation of myristicin was carried out by addition of $48 \%$ of hydrogen bromide $(\mathrm{HBr})$ with stirring at room temperature, then the reaction was terminated by cooling in ice, and the hydrohalogenation product was extracted with diethyl ether. The ether layers were collected, washed with distilled water and concentrated by rotary evaporator at $50^{\circ} \mathrm{C}$ and $100 \mathrm{rpm}$. The resultant oil was dissolved in methanol, stirred with $35 \% \mathrm{NH}_{4} \mathrm{OH}$ at room temperature to catalyze the amination reaction. After evaporation of the mixture, the resulting oil was dissolved in $10 \% \mathrm{HCl}$ and washed with ether. The $\mathrm{pH}$ was adjusted to 12 with the addition of $\mathrm{NaOH}$ pellets. The aqueous basic solution was extracted with ether, and the pooled ether extracts were evaporated till dryness under reduced pressure. The hydrohalogenation and/or amination reactions were monitored by precoated thin-layer chromatography (TLC) plates (silica gel $60, \mathrm{GF}_{254}$ (60-250 mesh), Merck, Germany) using a solvent system (hexane: methylene chloride (1:1)) and $p$-anisaldehyde sulfuric acid spray according to Gerlacha et al. [69], as visualizing agent. The TLC plates were heated for about $5 \mathrm{~min}$ at $100^{\circ} \mathrm{C}$, and resultant oil from hydrohalogenation and/or amination reactions was analyzed directly by GC-MS.

GC-MS analysis of synthesized MMDA. The chemical and enzymatic synthesized MMDA were analyzed by Agilent 6890 gas chromatograph equipped with an Agilent mass spectrometric detector, with a direct capillary interface fused with silica capillary column PAS- $5 \mathrm{~ms}(30 \mathrm{~mm} \times 0.32 \mathrm{~mm} \times 0.25 \mu \mathrm{m}$ film thickness). A $1 \mu$ sample in methanol was injected to the GC-MS [49], with helium as carrier gas at a flow rate of $1 \mathrm{ml} / \mathrm{min}$. The solvent delay was $3 \mathrm{~min}$ and the mass spectrometric detector was operated in electron impact ionization mode with an ionizing energy of 70 e.v. scanning from $\mathrm{m} / \mathrm{z} 50$ to 500 . The ion source temperature was $230^{\circ} \mathrm{C}$ and the electron multiplier voltage (EM voltage) was maintained at 1,250 v. The GC was manually tuned using perfluorotributyl amine, the temperature program was started at $70^{\circ} \mathrm{C}$ then elevated to $150^{\circ} \mathrm{C}$ at a rate of $15^{\circ} \mathrm{C} / \mathrm{min}$ and from $150^{\circ} \mathrm{C}$ to $250^{\circ} \mathrm{C}$ at a rate of $25^{\circ} \mathrm{C} / \mathrm{min}$ with $6 \mathrm{~min}$ hold time. The detector and injector temperature were set at $280^{\circ} \mathrm{C}$ and $250^{\circ} \mathrm{C}$, respectively. The putative names of the target compounds from the spectroscopic data were identified from Wiley and NIST spectral libraries.

\section{Results and Discussion}

Screening for Phenylalanine Ammonia-Lyase from Different Microbial Sources

Among 50 microbial isolates (20 fungal isolates, 20 bacterial isolates and 10 algal isolates) (Supplementary Data), four algal isolates, namely; A. flos-aquae, A. variabilis, S. platensis and C. vulgaris were selected for their promising yield of PAL. The crude PAL from the four algal isolates displayed visual forward and reverse PAL catalytic reactions on phenylalanine and cinnamic acid as substrates, respectively. The forward activities of PAL from A. flos-aquae, A. variabilis, S. platensis and C. vulgaris were $12.8,11.5,24.8$, and $10.8 \mu \mathrm{mol} / \mathrm{mg} / \mathrm{min}$, while the reverse activities were $23.3,19.6,49.6$, and $21.0 \mu \mathrm{mol} / \mathrm{mg} / \mathrm{min}$, respectively (Fig. 1C). These results revealed that S. platensis and A. flos-aquae displayed the highest PAL activities, thus, the enzyme from both sources has been further purified and characterized comparatively.

\section{Purification, Molecular Subunit Structure of PAL from Selected Algal Isolates}

The PAL was purified from the cultures of S. platensis and A. flos-aquae by gel-filtration and ion-exchange chromatographic approaches. The purification profile of PAL from S. platensis and A. flos-aquae was summarized in Table 1. The specific activities of PAL from S. platensis and A. flos-aquae were increased by about 1.7 and 1.3 folds than their corresponding crude enzymes with an overall yield of 73.3 and $87.1 \%$, respectively, upon acetone precipitation. By Sephadex $\mathrm{G}_{200}$ column, the specific activities of PAL from S. platensis and A. flos-aquae were increased by 2.9 and 2.4 folds with overall yield of 13.2 and $15.9 \%$, respectively. With the ion-exchange chromatography, the specific activities of PAL from S. platensis and A. flos-aquae were increased by 4.7 and 3.5 folds comparing to their crude enzymes, respectively. Consequently, the activity of PAL from S. platensis was

Table 1. Overall purification profile of PAL from S. platensis and A. flos-aquae.

\begin{tabular}{|c|c|c|c|c|c|c|c|c|c|c|}
\hline \multicolumn{6}{|c|}{ S. platensis } & \multicolumn{5}{|c|}{ A. flos-aquae } \\
\hline $\begin{array}{l}\text { Purification } \\
\text { step }\end{array}$ & $\begin{array}{l}\text { Total } \\
\text { activity } \\
\text { (U) }\end{array}$ & $\begin{array}{c}\text { Total } \\
\text { protein } \\
(\mathrm{mg})\end{array}$ & $\begin{array}{l}\text { Specific } \\
\text { activity } \\
\text { (U/mg) }\end{array}$ & $\begin{array}{l}\text { Purification } \\
\text { fold }\end{array}$ & $\begin{array}{c}\text { Recovery } \\
(\%)\end{array}$ & $\begin{array}{c}\text { Total } \\
\text { activity } \\
\text { (U) }\end{array}$ & $\begin{array}{c}\text { Total } \\
\text { protein } \\
(\mathrm{mg})\end{array}$ & $\begin{array}{l}\text { Specific } \\
\text { activity } \\
\text { (U/mg) }\end{array}$ & $\begin{array}{l}\text { Purification } \\
\text { fold }\end{array}$ & $\begin{array}{c}\text { Recovery } \\
(\%)\end{array}$ \\
\hline Crude & 10222 & 409.9 & 24.9 & 1 & 100 & 7598.6 & 588.9 & 12.9 & 1 & 100 \\
\hline $\begin{array}{l}\text { Acetone } \\
\text { precipitate }\end{array}$ & 7485 & 175.6 & 42.6 & 1.7 & 73.3 & 6619.1 & 400.1 & 16.5 & 1.2 & 87.1 \\
\hline $\begin{array}{l}\text { Gel } \\
\text { filtration }\end{array}$ & 1353 & 18.3 & 73.9 & 2.9 & 13.4 & 1210.7 & 39.64 & 30.5 & 2.3 & 15.9 \\
\hline $\begin{array}{l}\text { Ion-exchange } \\
\text { chromatography }\end{array}$ & 985 & 9.8 & 98.8 & 3.9 & 9.6 & 850 & 22.8 & 54.7 & 4.3 & 11.2 \\
\hline
\end{tabular}


A

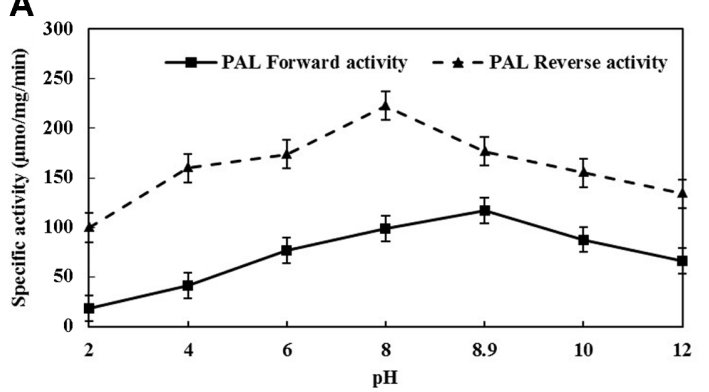

C

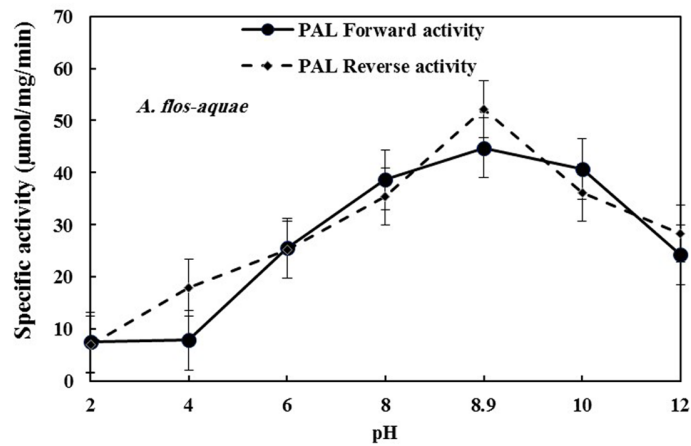

B

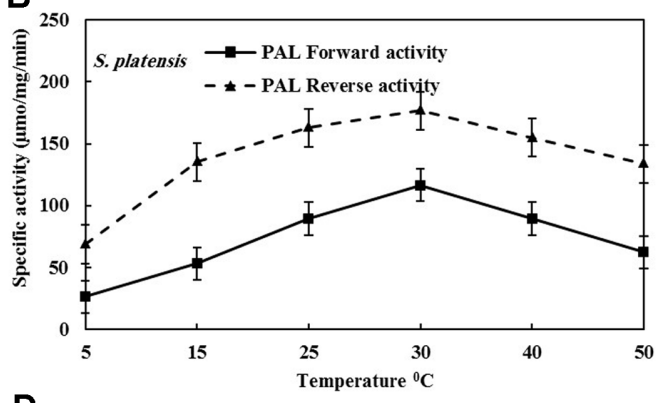

D

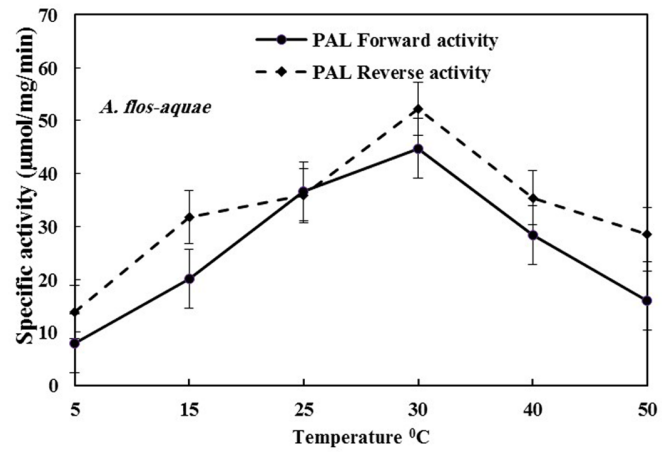

Fig. 2. Effect of different $\mathrm{pH}$ and temperature on specific activity of purified PAL from S. platensis (A and B) and A. flos-aquae (C and D), respectively. Each data point shows the average of at least three replicates. The standard errors are represented by vertical bars.

higher than A. flos-aquae by 1.3 folds with the last purification step. The active fractions from gel-filtration and ion-exchange chromatography were assessed based on their colorimetric activity and molecular homogeneity by denaturing PAGE. Prior to biochemical characterization, the most active and molecularly homogenous fractions were gathered and concentrated by dialysis with polyethylene glycol.

The subunit structure of PAL from S. platensis and A. flos-aquae was assessed by gel electrophoresis. SDS-PAGE analysis (Fig. 1D) showed a single protein band of molecular weight $64 \mathrm{kDa}$, revealing the homogeneity of the purified S. platensis and A. flos-aquae PAL. The molecular mass of recovered PAL is in coincidence with those reported for cyanobacterial PAL from A. variabilis and Nostoc punctiforme [10]. However, PAL from Trichosporon cutaneum [70] and Rhodotorula glutinis [11] showed 79 and $75 \mathrm{kDa}$, respectively.

Biochemical Characterization of PAL from S. platensis and A. flos-aquae

Optimum reaction temperature and $\mathrm{pH}$. The effect of reaction temperature and $\mathrm{pH}$ on the activity of PAL from both algal isolates was assessed. From the results (Fig. 2), the purified PAL from S. platensis had a maximum forward $(116.7 \mu \mathrm{mol} / \mathrm{mg} / \mathrm{min})$ and reverse activity $(176.7 \mu \mathrm{mol} / \mathrm{mg} / \mathrm{min})$ at $30^{\circ} \mathrm{C}$ incubation temperature. Also, at $30^{\circ} \mathrm{C}$, the maximum activity of $A$. flos-aquae PAL was 44.7 and $52.2 \mu \mathrm{mol} / \mathrm{mg} / \mathrm{min}$ for forward and reverse reactions. Being partially consistent, Moffitt et al., [10] reported that the optimum temperature of $A$. variabilis PAL was recorded at $40^{\circ} \mathrm{C}$, while the optimal activity of PAL of tobacco and sunflower was reported at 35 and $55^{\circ} \mathrm{C}$, respectively, and the optimum temperature of PAL of Rhizoctonia ranged from $44-46^{\circ} \mathrm{C}$ [4].

The highest activity of PAL of S. platensis was recorded at $\mathrm{pH}$ of 8.9 and 8 of forward and reverse reactions, respectively. Moreover, PAL derived from A. flos-aquae exhibited maximum activity of forward and reverse reactions at $\mathrm{pH}$ of 8.9. The optimal activity of $\mathrm{PAL}$ at this $\mathrm{pH}$ from both algal isolates were consistent with those reported for PAL production by A. variabilis [10] and within the optimum $\mathrm{pH}$ range for PAL $[4,8]$ from various microbial sources. Furthermore, PAL from the yeasts Trichosporon cutaneum [70] and Rhodotorula glutinis [11] had optimum $\mathrm{pH}$ at $8-9$, respectively.

Thermal stability, pH stability, inhibitors and activators of PAL. The thermal stability of PAL from both algal isolates was determined by pre-incubation of enzyme without substrate at various temperatures $(30,37$, and $45^{\circ} \mathrm{C}$ ). The residual enzyme activity was measured by the forward assay after 15, 30, 60, 120, and 180 min for each temperature degree. The profile of thermal stability of PALs was shown in Fig. 3. The half-life times of PAL from S. platensis at 30,37 , and $45^{\circ} \mathrm{C}$ were $9.5,3.2$, and $1.6 \mathrm{~h}$, respectively. Meanwhile, PAL from A. flos-aquae had halflife times of $12,9.0$, and $1.5 \mathrm{~h}$ at 30,37 , and $45^{\circ} \mathrm{C}$, respectively. Therefore, PAL from A. flos-aquae has a relatively higher stability than from $S$. platensis.

The $\mathrm{pH}$ stability of PAL was assessed by pre-incubation of enzyme without substrate at different $\mathrm{pH}$ ranges $(\mathrm{pH}$ range 4-10) using potassium phosphate buffer at $4^{\circ} \mathrm{C}$ for $2 \mathrm{~h}$, then the residual activity was determined as described above. PALs from both algal isolates displayed a higher stability at $\mathrm{pH}$ range 8-9, with dramatic 
A

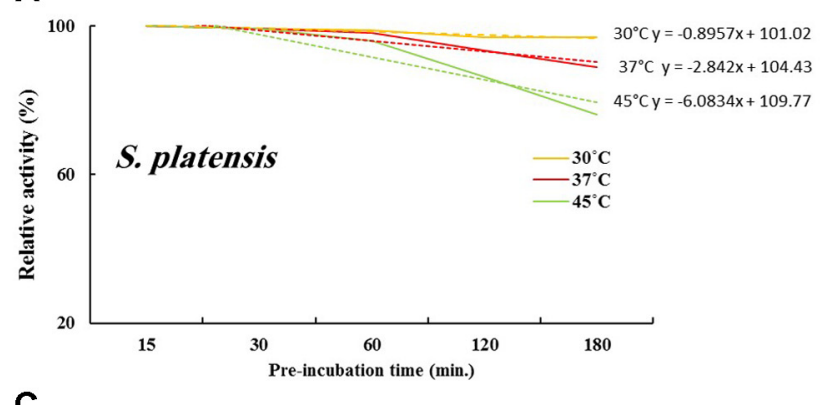

C

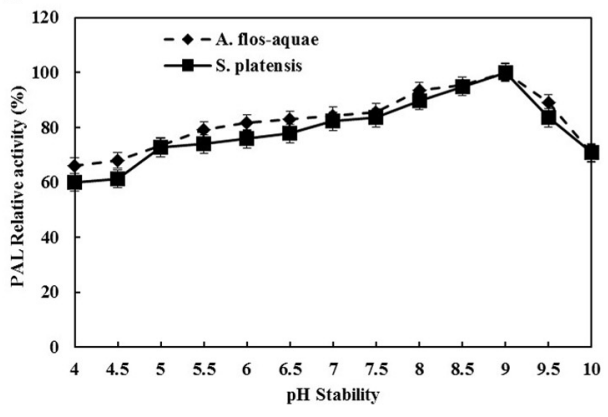

B

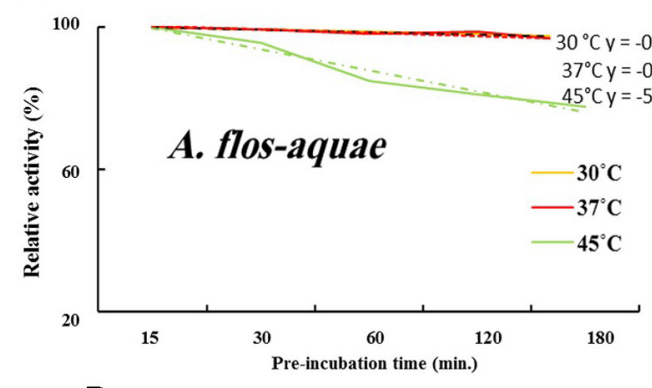

D

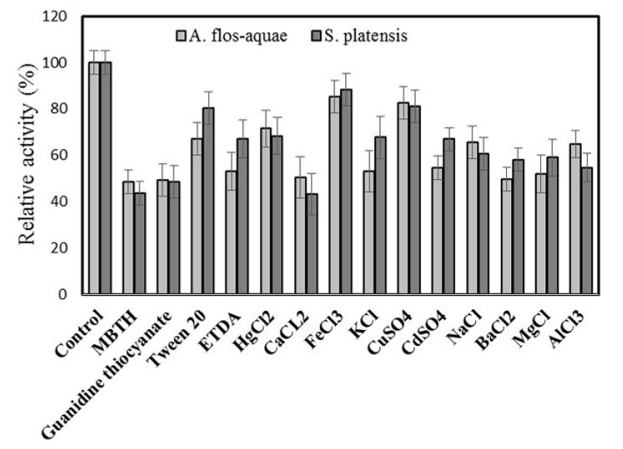

Fig. 3. Thermal stability (A\&B), pH stability (C), compounds and metals (D) of PAL from S. platensis and A. flos-aquae, respectively.

reduction to its activity at acidic $\mathrm{pH}$ and higher alkaline $\mathrm{pH}$ (Fig. 3C). Zhu et al. stated that activity of Rhodotorula glutinis $\mathrm{PAL}$ was stable at $\mathrm{pH}$ range of 6-10 [11].

The effect of various compounds and metals on activity of PAL was estimated by incubating the enzyme with each compound at $1 \mathrm{mM}$ final concentration for $2 \mathrm{~h}$ at $4^{\circ} \mathrm{C}$, then measuring the residual activity by the standard assay. Tested compounds such as 3-Methyl-2-benzo-thiazolinone hydrazone (MBTH), guanidine thiocyanate, Tween 20 and ethylenediaminetetraacetic acid (EDTA) and different metals such as $\mathrm{Na}^{+}, \mathrm{K}^{+}, \mathrm{Ca}^{2+}, \mathrm{Cu}^{2+}, \mathrm{Cd}^{2+}, \mathrm{Ba}^{2+}$, $\mathrm{Mg}^{2+}, \mathrm{Hg}^{2+}, \mathrm{Fe}^{3+}$, and $\mathrm{Al}^{3+}$ were used. By addition of compounds, the residual activity of PAL from S. platensis was maximally reported in presence of $\mathrm{FeCl}_{3}(88.2 \%)$, followed by $\mathrm{CuSO}_{4}(81.1 \%)$ and Tween $20(80.5 \%)$. On the other hand, $85.4 \%$ of PAL activity from $A$. flos-aquae remained after incubation with $\mathrm{FeCl}_{3}$, followed by $82.7 \%$ with $\mathrm{CuSO}_{4}$ and $\mathrm{HgCl}_{2}(71.4 \%)$ (Fig. 3D). It was reported that PAL activity from Cistanche deserticola was inhibited by $\mathrm{Hg}^{2+}, \mathrm{Zn}^{2+}$, and $\mathrm{pb}^{2+}$, while $\mathrm{Co}^{2+}, \mathrm{Fe}^{3+}$, and $\mathrm{Cu}^{2+}$ had no significant inhibitory effect [6]. Moreover, $\mathrm{Mg}^{2+}$ and $\mathrm{Ba}^{2+}$ were reported to be a slight activator for PAL activity [4].

Substrate specificity and kinetics of the purified PAL. The specificity of purified PALs from the two algal isolates towards different amino acids had been evaluated based on the standard forward assay. PALs from S. platensis and A. flos-aquae have affinity only toward tyrosine by $18.32 \%$ and $51.15 \%$, respectively, comparing to phenylalanine (Table 2). PALs from the two algal isolates have no activity on other amino acids such as methionine, glycine, asparagines, ornithine, lysine, arginine, alanine, cysteine and valine. These results are also consistent with those reported by MacDonald and D'Cunha [8].

Table 2. Substrate specificity of purified PAL from A. flos-aquae and S. platensis.

\begin{tabular}{lcccc}
\hline \multirow{2}{*}{ Substrate } & \multicolumn{2}{c}{ Anabaena flos-aquae } & \multicolumn{2}{c}{ Spirulina platensis } \\
\cline { 2 - 5 } & Specific activity $(\mathrm{U} / \mathrm{mg})$ & Relative activity (\%) & Specific activity (U/mg) & Relative activity (\%) \\
\hline Phenylalanine & 2.5 & 100 & 10.6 & 100 \\
Methionine & 0 & 0 & 0 & 0 \\
Glycine & 0 & 0 & 0 & 0 \\
Asparagine & 0 & 0 & 0 & 0 \\
Ornithine & 0 & 0 & 0 & 0 \\
Lysine & 0 & 0 & 0 & 18.4 \\
Tyrosine & 1.3 & 51.2 & 1.9 & 0 \\
Arginine & 0 & 0 & 0 & 0 \\
Alanine & 0 & 0 & 0 & 0 \\
Cysteine & 0 & 0 & 0 & 0 \\
Valine & 0 & 0 & & \\
\hline
\end{tabular}


Table 3. Kinetic parameters of PAL from S. platensis and A. flos-aquae for $L$-phenylalanine (L-PA) and transcinnamic acid (Trans-CA).

\begin{tabular}{|c|c|c|c|c|c|c|c|c|}
\hline \multirow[b]{2}{*}{ Substrate } & \multicolumn{4}{|c|}{ S. platensis } & \multicolumn{4}{|c|}{ A. flos-aquae } \\
\hline & $\begin{array}{c}\mathrm{K}_{\mathrm{m}} \\
(\mathrm{mM})\end{array}$ & $\begin{array}{c}\mathrm{V}_{\max } \\
(\mathrm{mM} / \mathrm{min})\end{array}$ & $\begin{array}{l}k_{\mathrm{cat}} \\
\left(\mathrm{s}^{-1}\right)\end{array}$ & $\begin{array}{c}k_{\mathrm{cat}} / \mathrm{K}_{\mathrm{m}} \\
\left(\mathrm{mMs}^{-1}\right)\end{array}$ & $\begin{array}{c}\mathrm{K}_{\mathrm{m}} \\
(\mathrm{mM})\end{array}$ & $\begin{array}{c}\mathrm{V}_{\max } \\
(\mathrm{mM} / \mathrm{min})\end{array}$ & $\begin{array}{l}k_{\mathrm{cat}} \\
\left(\mathrm{s}^{-1}\right)\end{array}$ & $\begin{array}{c}k_{\mathrm{cat}} / \mathrm{K}_{\mathrm{m}} \\
\left(\mathrm{mMs}^{-1}\right)\end{array}$ \\
\hline$L-\mathrm{PA}$ & 1.64 & 0.01 & 0.24 & 0.15 & 1.5 & 0.01 & 0.06 & 0.04 \\
\hline Trans-CA & 0.61 & 0.04 & 1.25 & 2.1 & 0.3 & 0.04 & 0.32 & 1.28 \\
\hline
\end{tabular}

The catalytic and kinetic parameters of the enzyme towards phenylalanine and cinnamic acid were summarized in Table 3. Different concentrations of $L$-phenylalanine and trans-cinnamic acid were tested and the activity of enzymes was measured by forward and reverse assay, respectively. PAL from both algal isolates displayed a higher affinity and velocity towards trans-cinnamic acid than $L$-phenylalanine. S. platensis PAL has a higher turnover number $\left(k_{\text {cat }}\right)$ and catalytic efficiency $\left(k_{\text {cat }} / \mathrm{K}_{\mathrm{m}}\right)\left(1.25 \mathrm{~s}^{-1}\right.$ and $2.03 \mathrm{mM}^{-1} \mathrm{~s}^{-1}$, respectively) than A. flos-aquae PAL $\left(32 \times 10^{-2} \mathrm{~s}^{-1}\right.$ and $1.28 \mathrm{mM}^{-1} \mathrm{~s}^{-1}$, respectively) toward trans-cinnamic acid as a substrate. Furthermore, turnover number and catalytic efficiency for S. platensis PAL $\left(24.4 \times 10^{-2} \mathrm{~s}^{-1}\right.$ and $14.9 \times 10^{-2} \mathrm{mM}^{-1} \mathrm{~s}^{-1}$, respectively) was higher toward $L$-phenylalanine than A. flos-aquae PAL $\left(6.6 \times 10^{-2} \mathrm{~s}^{-1}\right.$ and $4.4 \times 10^{-2} \mathrm{mM}^{-1} \mathrm{~s}^{-1}$, respectively). Whereas, the wild-type cyanobacterial PAL such as A. variabilis and Nostoc punctiforme had a higher turnover number $\left(k_{\text {cat }} 4.3 \mathrm{~s}^{-1}\right.$ and $1.96 \mathrm{~s}^{-1}$, respectively) and catalytic efficiency $\left(k_{\mathrm{cat}} / \mathrm{K}_{\mathrm{m}} 72.2 \mathrm{mM}^{-1} \mathrm{~s}^{-1}\right.$ and $43.8 \mathrm{mM}^{-1} \mathrm{~s}^{-1}$, respectively) using $L$-phenylalanine as substrate [10] comparing to our algal isolates. Moreover, PAL from Streptomyces maritimus had a smaller turnover number $\left(k_{\text {cat }} 0.0048 \mathrm{~s}^{-1}\right)$ and catalytic efficiency $\left(k_{\text {cat }} / \mathrm{K}_{\mathrm{m}} 2.1 \times\right.$ $\left.10^{-3} \mu^{-1} \mathrm{~s}^{-1}\right)$ toward $L$ - phenylalanine [71].

\section{Synthesis of MMDA}

Enzymatic synthesis of MMDA by PAL from S. platensis and A. flos-aquae. The transformation of myristicin with crude PAL of S. platensis and A. flos-aquae into MMDA was assessed, as described in Materials and Methods. After incubation of the reaction mixture, the enzyme activity was stopped, and the initial concentration of myristicin and developed MMDA was quantified. The enzymatic byproducts were checked by GC-MS analysis using chemically synthesized MMDA as authentic. As shown (Fig. 4), a new peak at 12.917 min for MMDA was observed other than the myristicin peak at $8.26-8.28 \mathrm{~min}$ as an enzymatic byproduct of S. platensis and A. flos-

A

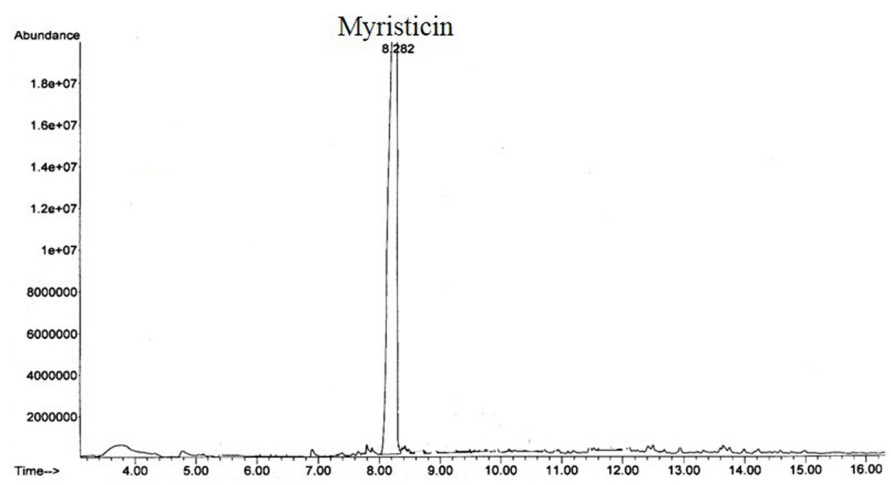

B

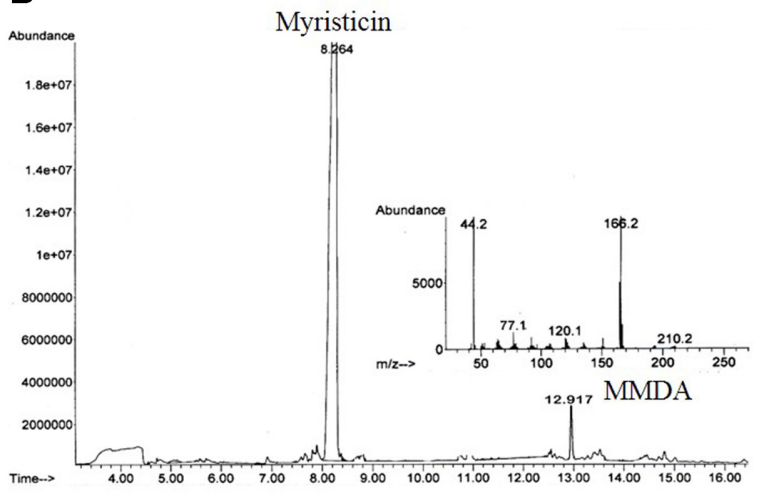

C

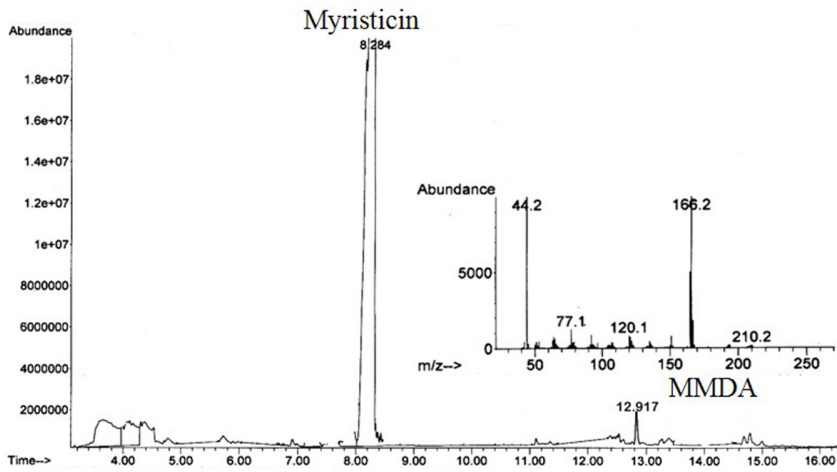

Fig. 4. Result of biotransformation of myristicin by PAL. GC chromatogram of blank (A) and reaction of myristicin with PAL from S. platensis (B) and A. flos-aquae (C) with mass fragmentation pattern of MMDA. 
A

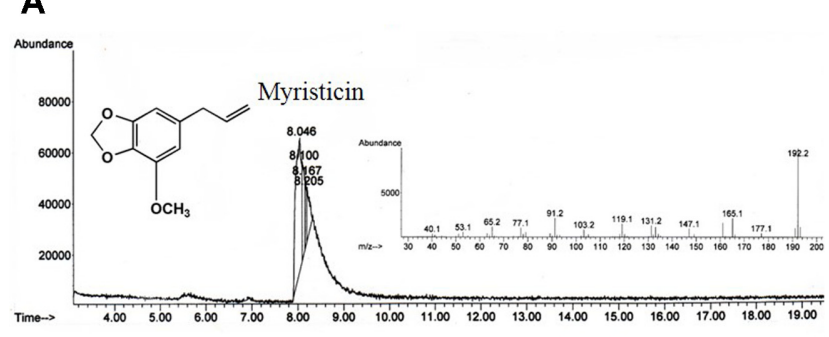

B

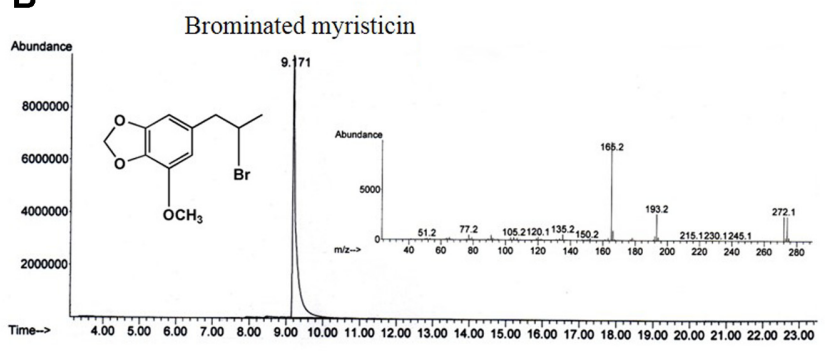

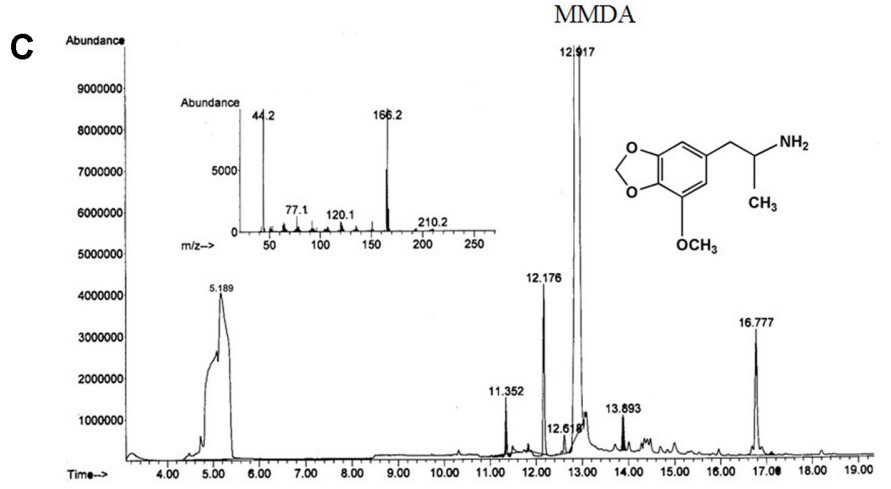

Fig. 5. Gas chromatography-mass spectrometry analysis of starting material, intermediate and product during chemical synthesis of MMDA; A, B and C: chromatograms and mass spectrum peaks of myristicin, brominated myristicin and MMDA, respectively.

aquae PAL, respectively. The enzymatic yield of MMDA was 15.3 and 10.6\% for PAL of S. platensis and A. flosaquae using myristicin substrate, respectively. Similarly, PAL from A. variabilis [72] and Rhodotorula glutinis [20] transformed trans-cinnamic acid into $L$-phenylalanine with a yield of about $73 \%$ and $70 \%$. In another work, Rhodotorula glutinis PAL produced $L$-phenylalanine methyl ester from trans-cinnamyl methyl ester in a biphasic system [73]. Furthermore, several reports investigated the hydroamination activity of PAL of microbial [74, 75] or plant origin [76-78].

Chemical synthesis of MMDA. From the GC-MS analysis (Fig. 5), a successful synthesis of MMDA from myristicin was accomplished. These results were similar to that reported about the synthesis of MMDA derivatives from nutmeg oil [49]. This is the first report dealing with the chemical manufacturing of MMDA from the natural product myristicin via hydrohalogenation and amination reactions. As can be seen from Fig. 6, mechanisms of hydrohalogenation and amination reactions were discussed in detail. Briefly, the electrophilic addition of hydrogen bromide to the side chain, propene group of myristicin gave 2-bromo-1-(3-Methoxy-4,5methylenedioxyphenyl)-2-propane (brominated myristicin) through the formation of the most stable secondary carbocation. In addition, amination reaction involves bimolecular nucleophilic substitution of ammonia with the

$1-$

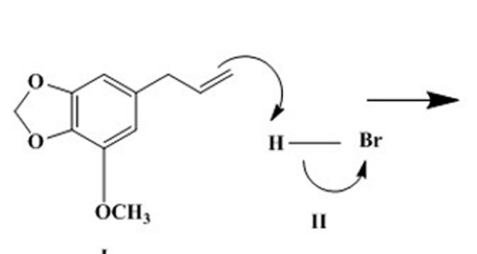

I

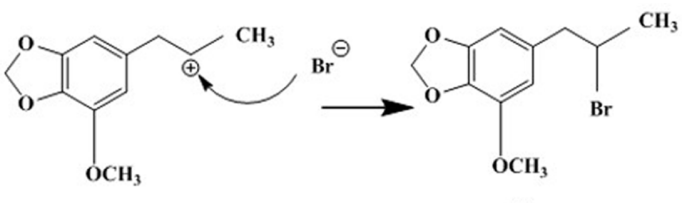

III<smiles>COc1cc(CC(C)(Br)C(C)(C)CN)cc2c1OCO2</smiles>

IV

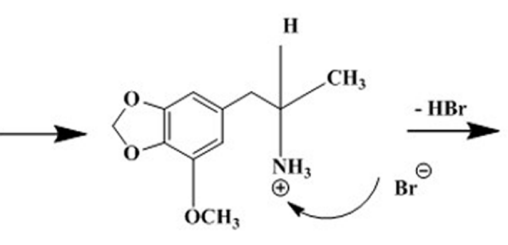

VI<smiles>COc1cc(CC(N)C(C)(C)C)cc2c1OCO2</smiles>

VII

Fig. 6. Schematic representation of chemical synthesis of MMDA from myristicin. 1: hydrohalogenation reaction; 2: amination reaction I: myristicin; II: hydrogen bromide; III: myristicin carbocation; IV: brominated myristicin; V: ammonia; VI: ammonium cation of MMDA; VII: MMDA 
intermediate, the brominated myristicin at $9.171 \mathrm{~min}$ to produce a desired product, MMDA at $12.917 \mathrm{~min}$. Moreover, the yield of the brominated myristicin and MMDA was $99.22 \%$ and $63.63 \%$, respectively.

Rationality and yield of MMDA from enzymatic and chemical methods. Biotransformation is the modification of a definite substance to its structurally related product by animal tissues, plants [79] and microorganisms [80, 81], as designated by white biotechnology [82]. Enzymes of microbial origin are preferred over those from animal or plant due to their economic production in a short period of time, high stability under extreme environments and feasibility of their purification [79, 83]. Free enzymes, whole cells and immobilized cells/enzymes are generally used as biological catalysts $[80,82]$. High reaction enantio-, stereo- and regioselectivity, minimal byproduct yield, mild reaction conditions and eco-friendliness are the advantages of microbial transformation [82, 84]. Utilization of biological catalysts instead of chemicals in chemical reactions offers great contribution to green chemistry [81, 85, 86] including industrial sectors like pharmaceuticals [80, 81, 87], cosmetics, and food [82]. From the results (Figs. 4 and 5), the actual yield of chemically synthesized MMDA was higher than those of $S$. platensis and A. flos-aquae PAL byproducts by about 5.9 and 4.15 folds, using the same concentration of myristicin as substrate. However, the multiple required steps and difficulty of purification of MMDA are the main hurdles that limit the chemical approach. Although enzymatic MMDA has a lower yield, the recovery process makes it more practical and commercially feasible than chemical approaches. Therefore, further optimization of the PAL reaction process for conversion of myristicin into MMDA are ongoing to achieve the maximum yield of MMDA.

In conclusion, A. flos-aquae, A. variabilis, S. platensis and C. vulgaris were used as a new source of PAL. Purification and characterization of PAL from S. platensis and A. flos-aquae were performed. Furthermore, chemical synthesis of MMDA from myristicin with a yield of $63.63 \%$ was carried out. Additionally, MMDA biosynthesis from myristicin by PAL was studied as an eco-friendly route for the first time. Hydroamination of myristicin with the purified PAL from S. platensis and A. flos-aquae to MMDA was successfully established in a one-step process with a yield of 15.3 and $10.6 \%$, respectively. Consequently, our future work will focus on the over expression and directed mutagenesis of $S$. platensis and A. flos-aquae PAL to get deeper insights into this enzyme active site structure and to increase the product yield.

\section{Acknowledgments}

We thank Prof. Dr. Eatedal Hassan Abdel-Aal, Faculty of Pharmacy, Zagazig University for her continuous guidance and advice during the chemical synthesis of MMDA.

\section{Conflict of Interest}

The authors have no financial conflicts of interest to declare.

\section{References}

1. Lovelock S. 2014. The development of novel biocatalysts for the asymmetric hydroamination of alkenes. Ph.D.Thesis, The University of Manchester, United Kingdom.

2. Koukol J, Conn E. 1961. The metabolism of aromatic compounds in higher plants. J. Biol. Chem. 236: 2692-2698.

3. Havir EA, Hanson KR. 1968. L-Phenylalanine ammonia-lyase. II. Mechanism and kinetic properties of the enzyme from potato tubers. Biochemistry 7: 1904-1914.

4. Hyun MW, Yun YH, Kim JY, Kim SH. 2011. Fungal and plant phenylalanine ammonia-lyase. Mycobiology 39: 257-265.

5. Lovelock SL, Turner NJ. 2014. Bacterial Anabaena variabilis phenylalanine ammonia lyase: a biocatalyst with broad substrate specificity. Bioorg. Med. Chem. 22: 5555-5557.

6. Hu GS, Jia JM, Hur YJ, Chung YS, Lee JH, Yun DJ, et al. 2011. Molecular characterization of phenylalanine ammonia lyase gene from Cistanche deserticola. Mol. Biol. Rep. 38: 3741-3750.

7. Tuan PA, Park NI, Li X, Xu H, Kim HH, Park SU. 2010. Molecular cloning and characterization of phenylalanine ammonia-lyase and cinnamate 4-hydroxylase in the phenylpropanoid biosynthesis pathway in garlic (Allium sativum). J. Agric. Food Chem. 58: 1091110917

8. MacDonald MJ, D'Cunha GB. 2007. A modern view of phenylalanine ammonia lyase. Biochem. Cell. Biol. 85: $273-282$.

9. Hemmati S. 2015. Phenylalanine ammonia-lyase through evolution: A bioinformatic approach. Trends Pharm. Sci. 1: 10-14.

10. Moffitt MC, Louie GV, Bowman ME, Pence J, Noel JP, Moore BS. 2007. Discovery of two cyanobacterial phenylalanine ammonia lyases: kinetic and structural characterization. Biochemistry 46: 1004-1012.

11. Zhu L, Cui W, Fang Y, Liu Y, Gao X, Zhou Z. 2013. Cloning, expression and characterization of phenylalanine ammonia-lyase from Rhodotorula glutinis. Biotechnol. Lett. 35: 751-756.

12. Löffelhardt W, Kindl H. 1976. Formation of benzoic acid and p-hydroxybenzoic acid in the blue green alga Anacystis nidulans: A thylakoid-bound enzyme complex analogous to the chloroplast system. Z Naturforsch C. 31: 693-699.

13. Fritz RR, Hodgins D, Abell C. 1976. Phenylalanine ammonia-lyase. Induction and purification from yeast and clearance in mammals. J. Biol. Sci. 251: 4646-4650.

14. MacDonald MC, Arivalagan P, Barre DE, MacInnis JA, D’Cunha GB. 2016. Rhodotorula glutinis Phenylalanine/tyrosine ammonia lyase enzyme catalyzed synthesis of the methyl ester of para-hydroxycinnamic acid and its potential antibacterial activity. Front. Microbiol. 7: 281.

15. Cui JD, Qiu JQ, Fan XW, Jia SR, Tan ZL. 2014. Biotechnological production and applications of microbial phenylalanine ammonia lyase: a recent review. Crit. Rev. Biotechnol. 34: 258-268.

16. Sarkissian CN, Kang TS, Gámez A, Scriver CR, Stevens RC. 2011. Evaluation of orally administered PEGylated phenylalanine ammonia lyase in mice for the treatment of Phenylketonuria. Mol. Genet. Metab. 104: 249-254.

17. Kim W, Erlandsen H, Surendran S, Stevens RC, Tyring SK, Matalon R, et al. 2004. Trends in enzyme therapy for phenylketonuria. Molecular Therapy. 10: 220-224.

18. Levy HL. 1999. Phenylketonuria: old disease, new approach to treatment. PNAS 96: 1811-1813.

19. Kovacs K, Banoczi G, Varga A, Szabo I, Holczinger A, Hornyanszky G, et al. 2014. Expression and properties of the highly alkalophilic phenylalanine ammonia-lyase of thermophilic Rubrobacter xylanophilus. PLoS One 9: e85943. 
20. Yamada S, Nabe K, Izuo N, Nakamichi K, Chibata I. 1981. Production of $L$-phenylalanine from trans-cinnamic acid with Rhodotorula glutinis containing L-phenylalanine ammonia-lyase activity. Appl. Environ. Microbiol. 42: 773-778.

21. Evans CT, Hanna K, Payne C, Conrad D, Misawa M. 1987. Biotransformation of trans-cinnamic acid to L-phenylalanine: optimization of reaction conditions using whole yeast cells. Enzyme. Microb. Technol. 9: 417-421.

22. Evans CT, Conrad D, Hanna K, Peterson W, Choma C, Misawa M. 1987. Novel stabilization of phenylalanine ammonia-lyase catalyst during bioconversion of trans-cinnamic acid to L-phenylalanine. Appl. Microbiol. Biotechnol. 25: 399-405.

23. Kot AM, Błażejak S, Kurcz A, Gientka I, Kieliszek M. 2016. Rhodotorula glutinis-potential source of lipids, carotenoids, and enzymes for use in industries. Appl. Microbiol. Biotechnol. 100: 6103-6117.

24. Sohilait HJ, Kainama H. 2015. Synthesis of Myristicin Ketone (3, 4-Methylenedioxy-5-Methoxyphenyl)-2-Propanone from Myristicin. Science 3: 62-66.

25. Sudradjat SE, Timotius KH, Mun'im A, Anwar E. 2018. The isolation of Myristicin from nutmeg oil by sequences distillation. J. Young Pharm. 10: 20-23

26. Carolina A, Maman M. 2016. Larvicidal activity of essential oils from the leaves and fruits of nutmeg (Myristica fragrans Houtt) against Aedes aegyptis (Diptera: Culicidae). Turkish JAF Sci. Technol. 4: 552-556.

27. de Cássia da Silveira e Sá R, Andrade LN, dos Reis Barreto de Oliveira R, de Sousa DP. 2014. A review on anti-inflammatory activity of phenylpropanoids found in essential oils. Molecules 19: 1459-1480.

28. Jana S, Shekhawat G. 2010. Anethum graveolens: An Indian traditional medicinal herb and spice. Pharmacogn. Rev. 4: 179-184.

29. Al-Jumaily EF, Al-Amiry MH. 2012. Extraction and Purification of Terpenes from Nutmeg (Myristica fragrans). J. Al-Nahrain Univ. Sci. 15: 151-160.

30. Lee JY, Park W. 2011. Anti-inflammatory effect of myristicin on RAW 264.7 macrophages stimulated with polyinosinicpolycytidylic acid. Molecules 16: 7132-7142.

31. Lee HS, Jeong TC, Kim JH. 1998. In vitro and in vivo metabolism of myristicin in the rat. J. Chromatogr. B Biomed. Sci. Appl. 705: 367372 .

32. Mao W, Zangerl AR, Berenbaum MR, Schuler MA. 2008. Metabolism of myristicin by Depressaria pastinacella CYP6AB3v2 and inhibition by its metabolite. Insect Biochem. Mol. Biol. 38: 645-651.

33. Braun U, Kalbhen D. 1973. Evidence for the biogenic formation of amphetamine derivatives from components of nutmeg. Pharmacology 9: 312-316.

34. Rahman N, Fazilah A, Effarizah M. 2015. Toxicity of Nutmeg (Myristicin): A Review. Int. J. Adv. Sci. Eng. Inf. Technol. 5: $212-215$.

35. Shulgin A, Sargent T, Naranjo C. 1973. Animal pharmacology and human psychopharmacology of 3-methoxy-4, 5methylenedioxyphenylisopropylamine (MMDA). Pharmacology 10: 12-18.

36. Snyder SH, Weingartner H, Faillace LA. 1970. DOET (2, 5-dimethoxy-4-ethylamphetamine) and DOM (STP)(2, 5-dimethoxy-4methylamphetamine), new psychotropic agents: their effects in man. Arch. Gen. Psychiatry 24: 50-55.

37. Benzenhöfer U, Passie T. 2010. Rediscovering MDMA (ecstasy): the role of the American chemist Alexander T. Shulgin. Addiction 105: 1355-1361.

38. Shulgin A. 1976. Psychomimétic agents ch. 4 in Maxwell Gordon, pp. 59-146. Psychopharmacological Agents, Ed.

39. Idle J. 2005. Christmas gingerbread (Lebkuchen) and Christmas cheer-review of the potential role of mood elevating amphetaminelike compounds formed in vivo and in furno. Prague Med. Rep. 106: 27-38.

40. Nozaki M, Vaupel D, Bright L, Martin W. 1978. A pharmacological comparison of 3-methoxy-4, 5-methylenedioxyamphetamine and LSD in the dog. Drug Alcohol Depend. 3: 153-163.

41. Snow O. 1998. Amphetamine Syntheses: Overview \& Reference Guide for Professionals, pp. 1-278. Ed. Thoth Press.

42. Passie T, Benzenhöfer U. 2018. MDA, MDMA, and other "mescaline-like" substances in the US military's search for a truth drug (1940s to 1960s). Drug Test Anal. 10: 72-80.

43. El-Sayed ASA, Khalaf SA, Ahmed HA. 2013. Characterization of homocysteine g-lyase from submerged and solid fermented cultures of Aspergillus fumigatus JX006238. J. Microbiol. Biotechnol. 23: 499-510.

44. El-Sayed ASA, Yassin M, Ibrahim H. 2015. Co-Immobilization of L-methioninase and glutamate dehydrogenase on polyacrylamide and chitosan for continuous production of L-homoalanine. Biotechnol. Appl. Biochem. 62: 514-522.

45. El-Sayed ASA, Fujimoto S, Yamada C, Suzuki H. 2010. Enzymatic synthesis of $\gamma$-glutamylglutamine, a stable glutamine analogue by $\gamma$-glutamyl transpeptidase from Escherichia coli K-12. Biotechnol. Lett. 32: 1877-1881

46. Naranjo C. 1974. The healing journey, pp. 1-235. Ed. Ballantine Books.

47. El-Sayed ASA, Shouman SA, Nassrat H. 2012. Pharmacokinetics, immunogenicity and anticancer efficiency of Aspergillus flavipes L-methioninase. Enzyme Microb. Technol. 51: 200-210.

48. Shulgin AT. 1964. 3-Methoxy-4, 5-methylenedioxy amphetamine, a new psychotomimetic agent. Nature 201: 1120-1121.

49. Clark CR, DeRuiter J, Noggle FT. 1996. Analysis of 1-(3-methoxy-4, 5-methylenedioxyphenyl)-2-propanamine (MMDA) derivatives synthesized from nutmeg oil and 3-methoxy-4, 5-methylenedioxybenzaldehyde. J.Chromatogr. Sci. 34: 34-42.

50. El-Sayed ASA, Abdel-Azim S, Ibrahim H, Yassin MA, Abdel-Ghany S, Esener S, Ali GS. 2015. Biochemical stability and molecular dynamic characterization of Aspergillus fumigatus cystathionine g-Lyase in response to various reaction effectors. Enzyme Microb. Technol. 81: 31-46

51. El-Sayed AS, Shindia AA, AbouZaid AA, Yassin AM, Ali GS, Sitohy MZ. 2019. Biochemical characterization of peptidylarginine deiminase-like orthologs from thermotolerant Emericella dentata and Aspergillus nidulans. Enzyme Microb. Technol. 124: 41-53.

52. Giri AV, Anandkumar N, Muthukumaran G, Pennathur G. 2004. A novel medium for the enhanced cell growth and production of prodigiosin from Serratia marcescens isolated from soil. BMC Microbiol. 4: 11.

53. Stanier R, Kunisawa R, Mandel M, Cohen-Bazire G. 1971. Purification and properties of unicellular blue-green algae (order Chroococcales). Bacteriol. Rev. 35: 171

54. Zarrouk C. 1966. Contribution a I'etude d'une cyanobacterie: Influence de divers facteurs physiques et chimiques et la photosynthese de Spirulina maxima (Setchell et Gardener) Geitler. Ph. D. Thesis, University of Paris, France.

55. Beakes GW, Canter HM, Jaworski GH. 1988. Zoospore ultrastructure of Zygorhizidium affluens and Z. planktonicum, two chytrids parasitizing the diatom Asterionella formosa. Can J. Botechnol. 66: 1054-1067.

56. Raju S, Sowmya S, Alexander Jebakumar P, Guruprasad R. 2014. Potent activator N-arylenamine-3-chloro-4-fluoroaniline for Phenylalanine Ammonia Lyase extracted from Plectranthus amboinicus. Int. J. Adv. Sci. Tech. Res. 4: 56-63.

57. Varga A, Bata Z, Csuka P, Bordea DM, Vertessy BG, Marcovici A, et al. 2017. Anovel phenylalanine ammonia-lyase from Kangiella Koreensis. Studia Universitatis Babes-Bolyai. Chemia. 62: 293-308.

58. Lowry OH, Rosebrough NJ, Farr AL, Randall RJ. 1951. Protein measurement with the Folin phenol reagent. J. Biol. Chem. 193: 265275.

59. Scopes RK. 2013. Protein purification: principles and practice, pp. 1-397. Ed. Springer Science \& Business Media, Springer New York.

60. El-Sayed A, Shindia A. 2011. Characterization and immobilization of purified Aspergillus flavipesl-methioninase: continuous production of methanethiol. J. Appl. Microbiol. 111: 54-69.

61. El-Sayed AS, Ibrahim H, Sitohy MZ. 2014. Co-immobilization of PEGylated Aspergillus flavipes L-methioninase with glutamate dehydrogenase: a novel catalytically stable anticancer consortium. Enzyme Microb. Technol. 54: 59-69. 
62. El-Sayed AS, Hassan MN, Nada HM. 2015. Purification, immobilization, and biochemical characterization of l-arginine deiminase from thermophilic Aspergillus fumigatus KJ 434941: Anticancer activity in vitro. Biotechnol. Prog. 31: 396-405.

63. El-Sayed AS, Shindia AA, Diab AA, Rady AM. 2014. Purification and immobilization of l-arginase from thermotolerant Penicillium chrysogenum KJ185377. 1; with unique kinetic properties as thermostable anticancer enzyme. Arch. Pharm. Res. [Online ahead of print]

64. El-Sayed AS, Ruff LE, Ghany SEA, Ali GS, Esener S. 2017. Molecular and spectroscopic characterization of Aspergillus flavipes and Pseudomonas putida L-methionine $\gamma$-lyase in vitro. Appl. Biochem. Biotechnol. 181: 1513-1532.

65. Lim H-W, Park S, Lim C. 1997. Purification and properties of phenylalanine ammonia-lyase from leaf mustard. Mol. Cells 7: 715-720.

66. Laemmli UK. 1970. Cleavage of structural proteins during the assembly of the head of bacteriophage T4. Nature 227: 680-685.

67. You CX, Jiang HY, Zhang WJ, Guo SS, Yang K, Lei N, et al. 2015. Contact toxicity and repellency of the main components from the essential oil of Clausena anisum-olens against two stored product insects. J. Insect Sci. 15: 87.

68. Passreiter CM, Akhtar Y, Isman MB. 2005. Insecticidal activity of the essential oil of Ligusticum mutellina roots. Z. Naturforsch C. 60: 411-414.

69. Gerlacha AdCL, Gadeac A, da Silveirab RMB, Clerca P, Lohézic-le Dévéhatc F. 2018. The Use of anisaldehyde sulfuric acid as an alternative spray reagent in TLC analysis reveals three classes of compounds in the genus Usnea adans.(Parmeliaceae, lichenized Ascomycota). Preprints 2018, 2018020151 (doi: 10.20944/preprints201802.0151.v1)

70. Goldson-Barnaby A, Scaman CH. 2013. Purification and characterization of Phenylalanine ammonia lyase from Trichosporon cutaneum. Enzyme Res. 2013: 670702 .

71. Louie GV, Bowman ME, Moffitt MC, Baiga TJ, Moore BS, Noel JP. 2006. Structural determinants and modulation of substrate specificity in phenylalanine-tyrosine ammonia-lyases. Chem. Biol. 13: 1327-1338.

72. Weise NJ, Parmeggiani F, Ahmed ST, Turner NJ. 2018. Discovery and investigation of mutase-like activity in a phenylalanine ammonia lyase from Anabaena variabilis. Top Catal. 61: 288-295.

73. D'cunha GB, Satyanarayan V, Nair PM. 1994. Novel direct synthesis of $L$-phenylalanine methyl ester by using Rhodotorula glutinis phenylalanine ammonia lyase in an organic-aqueous biphasic system. Enzyme Microb. Technol. 16: 318-322.

74. Weise NJ, Ahmed ST, Parmeggiani F, Galman JL, Dunstan MS, Charnock SJ, et al. 2017. Zymophore identification enables the discovery of novel phenylalanine ammonia lyase enzymes. Sci. Rep. 7: 13691.

75. Rowles I, Groenendaal B, Binay B, Malone KJ, Willies SC, Turner NJ. 2016. Engineering of phenylalanine ammonia lyase from Rhodotorula graminis for the enhanced synthesis of unnatural l-amino acids. Tetrahedron 72: 7343-7347.

76. Dreßen A, Hilberath T, Mackfeld U, Billmeier A, Rudat J, Pohl M. 2017. Phenylalanine ammonia lyase from Arabidopsis thaliana (AtPAL2): a potent MIO-enzyme for the synthesis of non-canonical aromatic alpha-amino acids: Part I: comparative characterization to the enzymes from Petroselinum crispum (PcPAL1) and Rhodosporidium toruloides (RtPAL). J. Biotechnol. 258: 148-157.

77. Bartsch S, Wybenga GG, Jansen M, Heberling MM, Wu B, Dijkstra BW, et al. 2013. Redesign of a phenylalanine aminomutase into a phenylalanine ammonia lyase. ChemCatChem. 5: 1797-1802.

78. Bartsch S, Bornscheuer UT. 2010. Mutational analysis of phenylalanine ammonia lyase to improve reactions rates for various substrates. Protein Eng. 23: 929-933.

79. Sabu A, Nampoothiri KM, Pandey A. 2005. L-Glutaminase as a therapeutic enzyme of microbial origin, pp. 75-90. Microbial Enzymes and Biotransformations.

80. Smitha M, Singh S, Singh R. 2017. Microbial biotransformation: a process for chemical alterations. J. Bacteriol. Mycol. Open Access. 4: 00085

81. Hegazy M-EF, Mohamed TA, ElShamy AI, Abou-El-Hamd HM, Mahalel UA, Reda EH, et al. 2015. Microbial biotransformation as a tool for drug development based on natural products from mevalonic acid pathway: a review. J. Adv. Res. 6: 17-33.

82. Patra S. 2007. Biotransformation of caffeine to value added products. Ph.D.Thesis, University of Mysore.

83. Gopinath SC, Anbu P, Arshad M, Lakshmipriya T, Voon CH, Hashim U, et al. 2017. Biotechnological processes in microbial amylase production. Biomed. Res. Int. 2017: 1272193.

84. Schauer F, Borriss R. 2004. Biocatalysis and Biotransformation, pp. 237-306. In Tkacz JS, Lange L (eds.), Advances in Fungal Biotechnology for Industry, Agriculture, and Medicine, Ed. Springer US, Boston, MA

85. Milner SE, Maguire AR. 2012. Recent trends in whole cell and isolated enzymes in enantioselective synthesis. Review Accounts 321382.

86. Li Z, Held M, Panke S, Schmid A, Mathys R, Witholt B. 2007. Biocatalysis for Industrial Green Chemistry, pp. 281-298. Methods and reagents for green chemistry: an introduction, Ed. John Wiley \& Sons, Inc.

87. Boaventura MAD, Lopes RF, Takahashi JA. 2004. Microorganisms as tools in modern chemistry: the biotransformation of 3indolylacetonitrile and tryptamine by fungi. Braz. J. Microbiol. 35: 345-347. 